\title{
MICROFINANCE INSTITUTIONS \\ ON THE REMITTANCES MARKET: \\ DO MONEY TRANSFER ACTIVITIES GENERATE DEPOSITS?
}

RITHA SUKADI MATA ${ }^{1}$

\begin{abstract}
Microfinance institutions (MFIs) are expected to succeed in transforming migrants' remittances into deposits. Based on an original database including 114 MFIs from Africa, South Asia, Latin America and the Caribbean, and East Asia and the Pacific, this paper empirically examines the occurrence of this expected success. It tests whether MFIs operating on the remittances market capture more deposits than others. The results exhibit a positive and significant effect of the money transfer activity on the amounts of deposits in MFIs.
\end{abstract}

Keywords: remittances, deposits, microfinance.

JEL Classification: G21, O15, O16, O17.

\section{INTRODUCTION}

Officially recorded remittances to developing countries amounted to 325 billion USD in 2010 (World Bank, 2011). They constitute the second largest source of external finance for those countries, after foreign direct investment. Given the increasing importance of remittances in total international capital flows, there is growing literature on the relationship between remittances and development (see for instance Azam and Gubert, 2005; Amuedo-Dorantes and Pozo, 2006; Faini, 2007). Recent studies have highlighted the role of financial intermediaries as determinants of the impact of remittances on long-term growth of the receiving countries (Mundaca, 2009; Giuliano and Ruiz-Arranz, 2009). Despite that the majority of migrants and remittance receivers in developing countries are unbanked and, potential, clients of MFIs, the relationship between remittances, microfinance and growth has not been

1 Université Libre de Bruxelles, SBS-EM, Centre Emile Bernheim, 50 Av. FD Roosevelt CP145/1, 1050 Brussels, Belgium. Email: rsukadim@ulb.ac.be. 
adequately studied. This paper analyses the role of microfinance institutions (MFIs) as financial intermediaries between remittance receivers and the formal economy. Through an empirical analysis, it tests whether MFIs are able to turn remittances into deposits that can be used to fund investment projects and thus contribute to growth.

The relationship between remittances, financial development and growth is ambiguous. In fact, well-functioning financial markets may help direct remittances to projects that yield the highest return and thus enhance growth rates, thanks to low cost of conducting transactions. In this case, remittances impacting on growth should increase with the level of financial development. Mundaca (2009) found empirical evidence for remittances and financial development as complements for growth, thanks to remittances recycled into lendable funds. However, remittances may become a substitute for inefficient or nonexistent credit markets by helping local entrepreneurs to reduce their credit constraints, which can play a critical role in determining growth prospects in economies characterized by a high level of income inequality (Aghion et al., 1999) ${ }^{2}$. In this case, the impact of remittances on formal investment should decrease with the level of financial development. Giuliano and Ruiz-Arranz (2009) found evidence for this. Gheeraerts et al. (2010) have both found these two opposite effects of the financial development on the impact of remittances on growth: when financial development increases, the cost of holding a deposit account decreases and more remittances can be recycled into the financial system and then be used for investments (complements), while at the same time, the cost of borrowing on external market decreases, which reduces the necessity for remittances to serve as lendable funds (substitutes).

It appears that the ability for remittances to fund formal investments depends on the remittance receivers' access to financial institutions. Thus, through their capacity to take deposits, financial institutions raise migrants' ability to save. Furthermore, given their ability to engage in financial intermediation, they increase the likelihood that migrants' deposits are channeled into productive investments (Amuedo-Dorantes and Bansak, 2006). According to Orozco (2007), the majority of migrants are excluded from using banking services. This lack of access is due to various barriers that can be related

2 In this case, remittances boost investments in a more limited way, as they only finance migrants and/or receivers projects, while when recycled into the financial system, they can be used to fund any of the projects identified by financial intermediaries. It is, however, important to stress that future-flows of remittances from workers have been used by banks in emerging countries such as Turkey and Brazil to raise capital from international markets, contributing to avoid credit rationing (Giuliano and Ruiz-Arranz, 2009). 
to physical access, affordability and eligibility (Beck et al., 2008). In terms of physical access, customers may have to visit remote bank headquarters to open their accounts, instead of local bank branch offices. They could also face affordability problems as the minimum balances and fees may be high. Finally, the requirements in terms of necessary documents to open a bank account or necessity to have a job in the formal sector can be perceived as eligibility barriers. MFIs contribute in lowering costs of conducting financial transactions across these three dimensions of barriers, thanks to methodologies such as joint liability or presence in rural areas ${ }^{3}$. Microfinance should then be considered when studying the impact of remittances on growth in developing countries, as MFIs are financial intermediaries that should be able to provide the majority of migrants and remittance receivers with deposit facilities.

MFIs are able to gain access to remittance flows either by their clients who may be recipients and decide to deposit a share of the amounts received, or by providing a money transfer service (see Isern et al., 2006 for how MFIs can operate on the money transfer market). In the latter case, MFIs may encourage migrants and recipients to deposit their savings, thanks to the supply of adapted deposit facilities ${ }^{4}$. For that matter, literature encourages MFIs to operate on the money transfer market, so they are able to gain access to additional financial resources. (See Sukadi Mata (2010) for literature on motivating factors for MFIs to enter the money transfer market.) However, if empirical studies exist on the impact of remittances on savings at a macroeconomic level (Aggarwal et al., 2006; Gupta et al., 2009), as well as on the effect of access to banking services on migrants' savings (Amuedo-Dorantes, and Bansak 2006), to our knowledge, the hypothesis of a positive effect of remittance flows on deposits in MFIs has not been econometrically tested yet ${ }^{5}$.

Using an original database of 114 MFIs operating in Latin America and the Caribbean (LAC), South Asia (SA), East Asia and the Pacific (EAP), and Africa, this paper studies whether MFIs are able to capture migrants' savings thanks to their money transfer activity. We test the effect of money transfer activity on deposits. The sample is comprised of financial statements reported to the MIX market (by the end of November 2008) by MFIs that collect

\footnotetext{
3 Extensive literature exists on microfinance. See for instance Gonzalez-Vega (1998) and Armendariz and Morduch (2009).

4 According to Orozco and Hamilton (2006), on 29 MFIs studied in Latin America, $41.5 \%$ of them offered to remittance receivers their typical services and $14 \%$ had elaborated tailored packages for remittance receivers.

5 The relationship between remittance and microfinance has often been studied through case-studies. See for instance Orozco and Hamilton (2006) and Ponsot (2006).
} 
voluntary savings from their clients. The study was realized with 2004 and 2006 data, where 2006 being the year in which information on the supply of money transfer services within the MFI was collected.

The principal result we found suggests that money transfer activity has a significant positive effect on deposits. MFIs involved on the remittance market thus attract more deposits than the others, probably coming from migrants and remittance receivers. This positive effect may be explained by the induced lower transaction costs for remittance receivers to deposit their money in a financial institution ${ }^{6}$. Results suggest that increasing the supply of money transfer activities through MFIs should contribute to improve the impact of remittances on growth.

The rest of the paper is organized as follows: Section 2 examines what are the potential explanatory variables for deposits; Section 3 outlines methodology and data; Section 4 provides empirical results; Section 5 concludes.

\section{POTENTIAL EXPLANATORY VARIABLES FOR DEPOSITS}

Various factors can influence the amount of deposits collected by a MFI. Even if we control for other elements, such as the economy, remittance inflows within the country, and the legal status of the MFI, we, in particular, test the relevance of an indicator: the money transfer activity.

\section{Money transfer activity}

Migrants and remittance receivers are in need of financial services and are willing to put their savings in a financial institution as long as adapted financial products are available (Acción Insight, 2004; Orozco and Fedewa, 2005). Furthermore, remittances can create not only a need for financial products from receivers, but are able to make these persons eligible for further financial products. Remittance receivers may primarily come to a MFI for the money transfer service offered, and then because of further financial

\footnotetext{
6 Transaction costs refer here to the costs incurred by the receivers in order to put their savings in a financial institution once they have received remittances. As receivers are mainly excluded from traditional banks and are potential clients for MFIs, through the money transfer activity provided by the MFI they can at the same time have access to remittances and to deposit facilities. It is therefore less costly compared to if they had to go to a traditional bank for the money transfer service, and then go in an MFI to deposit their money. In this paper we do not directly test the occurrence of economies on transaction costs, as we do not compare MFIs to banks or any other financial intermediary.
} 
services made available to them in this MFI, for example: deposit solutions. In this case, all else being equal, the money transfer activity (MTA) should contribute to increasing deposits in the MFI. By providing money transfer services, MFIs may also contribute to the increase of competition on the market, which should lead to reduced sending fees and allow remitters to realize economies (Orozco, 2007). In this case, the money available for deposits should increase.

The hypothesis is that MTA will have a positive effect on the volume of deposits collected by the MFIs, as this activity brings new depositors among the remitters and the remittance receivers, and because it is able to increase remittance flows.

\section{Additional controls: MFI characteristics}

As, according to our knowledge, no other study has try to empirically explain the volume of deposits mobilized by MFIs, we included here a set of variables that we consider as potential determinants of clients' ability and clients' motivation to deposit their savings in a given MFI.

We have firstly included a measure of the poverty of the clientele served by MFIs, the average size of loans (ALS), which gives an indication on individuals' ability to save.

Secondly, we have also included a measure of the remuneration of the deposits, the financial expense ratio $\left(F E R_{i}\right)$, measured as financial expense, or expenses on funding liabilities) / average total assets ${ }^{7}$. A high remuneration should motivate deposits within the institution; however, according to relevant literature, the 'poor' value the opportunity to have their money kept in a safe place more than the interest rate offered by the institution (see for instance Deshpande and Glisovic-Mezieres, 2007 and Wright, 2003).

Thirdly, we have included a measure of the interest rate charged on loans, approximated by the MFI financial revenue ratio $\left(F R R_{i}\right)$, measured as financial revenue, or income generated by loan portfolio) / average total assets ${ }^{8}$. The interest directly charged affects the individual's ability to save, as it has an impact on their revenues.

Finally, we included proxies for the trust toward the institution ${ }^{9}$, namely

\footnotetext{
7 www.mixmarket.org and Microrate and IADB (2003).

8 www.mixmarket.org and Microrate and IADB (2003).

9 See for instance Hossain, M.A., Lab-Oyan, G., Larcombe, K. and K.R. Sapkota (2005), “Developing or strengthening savings operations. What is involved", in Hirschland (2005), who argue that people will deposit their savings in an institution only if they perceive it to be trustworthy.
} 
a dummy for the legal status of the MFI (Bank, Cooperative, Non-profit, Nonbank financial institution, Rural banks), and the size of the institution ${ }^{10}$ (Assets).

Our sample only comprises MFIs which collect voluntary savings, therefore adding an indicator of their regulatory environment as an explanatory variable is not necessary. In fact, regulation does not impact the amount of savings that can be collected by institutions, rather on the opportunity to collect savings or not.

\section{Additional controls: Macroeconomic indicators}

Following Aggarwal et al., (2011) and Gupta et al., (2009), who studied the impact of remittances on financial development, measured by the level of bank deposits expressed as a percentage of the gross domestic product or GDP, we have included in our specification a measure of remittance flows, remittance inflows to the receiving country's GDP (Rem/GDP). We have also measures of the country level of development, namely the GDP per capita in constant US dollars (GDPpc) and GDP changes in one year $(\triangle G D P(-1))$ and two years $(\triangle G D P(-2))$. Finally, we have a measure of the financial sector openness, the private capital inflows (KInflows $\left.{ }^{11}\right)$, and a measure of the inflation, the annual percentage change in the Consumer Price Index $(\triangle C P I)$.

We have also included a measure of financial inclusion, which was not in the specification of Aggarwal et al., (2011). According to Amuedo-Dorantes and Bansak (2006), access to banking services could increase amounts remitted and encourage migrants to save. The indicator used is the percentage of the adult population with access to an account with a financial intermediary in the country (FinInclusion), provided by Beck et al. (2008)12.

\section{METHODOLOGY AND DATA}

In order to test the hypothesis defined in the previous section and analyze the effect of a MTA on the volume of deposits collected by an MFI over

10 From the client's perspective, the size (measured by the volume of MFI's activities) can be considered as a confidence parameter, while from a managerial point of view, the size is used as a proxy for MFI efficiency. Both confidence and efficiency increase with size. flows.

11 According to Huang (2006), this measure of openness is related to control of capital

12 Financial intermediaries refer to all types of financial institutions available in a given country (mainly banks, but, as they are not explicitly excluded from the database, MFIs are also included in the measure; however, their proportion compared to the whole sample is not given). 
the period 2004-2006, we specify a cross-section model, where the dependant variable is the natural $\log$ arithm of Deposits $(\log D)^{13}$.

The explanatory variable of interest is the binary variable MTA: it takes value 1 if the MFI has a MTA and 0 otherwise. The dummy MTA has been built based on the MIX database. The MIX only gives information about the availability of an MTA in the MFI. It does not give information neither on the moment this service was launched nor whether the MFI deals with international and / or domestic money transfers. According to Orozco (2008), the majority of MFIs started to operate on the money transfer market in 200514. We then collected data for the year 2004, in order to see whether the MTA significantly contributed to increase the volume of deposits collected by MFIs over this period (between 2004 and 2006).

We also control for additional variables: the poverty of clients, the size of the deposit remuneration and interest paid on loans, MFI size and legal status, country's level of performance, country's inflation, openness of the financial sector and the level of financial inclusion in the country.

Hence, the following model is estimated:

$$
D_{i, t}=\alpha_{i}+\beta_{1} M T A_{i, t}+\beta_{x} X_{i, t}+\varepsilon_{i, t}
$$

Where $D$ is the indicator of the volume of deposits collected by the MFI $i$ at time $t$, and it is measured as the natural logarithm of deposits. MTA is the dummy for the occurrence of money transfer activity in the MFI. $X$ is a vector of macroeconomic and institutional explanatory variables, described in the previous section.

\section{The data}

MFIs voluntarily participate in the MIX Market database and have to enclose documentation that supports the data, such as annual reports and audited financial statements. Therefore, the database is a sample of best managed MFIs in the world, as they should have an adequate information structure to provide required documentation (Krauss and Walter, 2008). We have included in our sample only the MFIs that collect deposits. Basic statistics

13 This ratio is positively correlated with the volume of deposits collected by a MFI (significant at $5 \%$ ).

14 In a subsample of 60MFIs operating in LAC, Africa and Asia and included in a survey realized in 2008, 75\% of MFIs started to offer a MTA after 2004 (among which 2/3 started between 2005 and 2006). For the details of the survey, see Orozco (2008). 
obtained from our sample appear to be similar to the overall MIX database statistics. For instance, the FER of our sample is $4.7 \%$, compared to $5 \%$ for the larger MIX database. The FRR is around 23\% for our sample, compared to $24 \%$ for the MIX. However, in terms of loan size, MFIs in our sample lend on average larger amounts compared to the overall MIX database, US\$ 900 compared to US\$ 725.

We use observations from 114 MFIs in Latin America and the Caribbean (LAC), South Asia (SA), East Asia and the Pacific (EAP), and Africa. The sample is comprised of the 114 MFIs for which all the needed information was made available for the years considered, i.e. 2004 and 2006 15 . The sample is divided into 2 groups of MFIs which are: the ones that had a MTA in 2006 (34 MFIs or 30\% of the sample), and those that did not ( 80 MFIs, or 70\% of the sample).

Regarding macroeconomic indicators, remittances are computed by statistical agencies, such as the International Monetary Fund (IMF), the United Nations (UN), or the World Bank, as the sum of three items in the Balance of Payments, i.e., (1) compensation of non-resident employees, (2), workers' remittances, and (3) migrant transfers. The two first items belong to the current account, through income and current transfers respectively, and the last item to the capital account, through capital transfers. Aggarwal et al. (2006) and Alferi et al. (2005) take an in depth look into the definition of remittances. We use the World Bank database on remittance inflows worldwide. MFIs variables come from the MIX. Other macroeconomic variables come from the World Economic Outlook Database (WEO) of the IMF (GDP, GDPpc, $\triangle C P I$, KInflows) and from Beck et al. (2008) database (FinInclusion) ${ }^{16}$.

Table 1 shows the summary statistics of the continuous variables of our sample. Statistics are given for each of the 2 groups of the sample. The difference regarding the mean between groups is significant for the dependant variable $\log D($ at $1 \%$ ), the inflation (at 5\%), the standard of living measured by the GDPpc (at 10\%) and the size (at 1\%). The average level of $D$ is significantly higher for MFIs with a MTA than for the others. Regarding inflation, MFIs that have an MTA are located in countries which have experienced a lower level of inflation on average (4.55\%), compared to other MFIs $(6.23 \%)$.

15 The list of MFIs of the sample is in the appendix.

16 Data collected between 2004 and 2005. 
Table 1: Explanatory continuous variables descriptive statistics

\begin{tabular}{|c|c|c|c|c|c|c|}
\hline Variable & Description & $\begin{array}{l}\text { MTA } \\
\text { status }\end{array}$ & Mean & $\begin{array}{l}\text { Std. } \\
\text { Dev }\end{array}$ & Min & Max \\
\hline \multirow[t]{2}{*}{$\mathrm{D}$} & \multirow[t]{2}{*}{ Natural logarithm of Deposits } & 0 & 6.23 & 1.02 & 4 & 8 \\
\hline & & 1 & 7.11 & 1.34 & 2 & 10 \\
\hline \multirow[t]{2}{*}{ REM/GDP } & Remittance inflows/ & 0 & 7.41 & 5.5 & 0.22 & 26 \\
\hline & Gross Domestic Product (\%) & 1 & 7.23 & 6.41 & 1 & 26 \\
\hline \multirow[t]{2}{*}{ GDPpc } & \multirow{2}{*}{$\begin{array}{l}\text { Gross Domestic Product per capita } \\
\text { (US\$) }\end{array}$} & 0 & 2945 & 1588 & 700 & 6972 \\
\hline & & 1 & 3905 & 2209 & 942 & 9694 \\
\hline \multirow[t]{2}{*}{$\Delta \mathrm{GDP}(-1)$} & Annual percentage change in the & 0 & 10.78 & 15.25 & -52 & 30 \\
\hline & Gross Domestic Product (\%) & 1 & 10.52 & 11.97 & -52 & 30 \\
\hline \multirow[t]{2}{*}{$\Delta \mathrm{GDP}(-2)$} & 2 years percentage change in the & 0 & 22.32 & 18.04 & -47 & 43 \\
\hline & Gross Domestic Product (\%) & 1 & 22.97 & 14.58 & -47 & 43 \\
\hline \multirow[t]{2}{*}{$\Delta \mathrm{CPI}(-1)$} & \multirow{2}{*}{$\begin{array}{l}\text { Annual percentage change in the } \\
\text { consumer price index (CPI) }\end{array}$} & 0 & 6.23 & 3.64 & 0.05 & 13 \\
\hline & & 1 & 4.55 & 3.26 & 2 & 14 \\
\hline \multirow[t]{2}{*}{ KInflows } & (Foreign direct investment + Portfolio & 0 & 15 & 14.64 & 0.08 & 54 \\
\hline & investment + other investment)/GDP & 1 & 14 & 10.51 & 0.08 & 33 \\
\hline \multirow{3}{*}{$\begin{array}{l}\text { Country } \\
\text { FinIncl. }\end{array}$} & \multirow{3}{*}{$\begin{array}{l}\text { Adult population with access to an } \\
\text { account with a financial intermediary } \\
\text { in the country }(\%)\end{array}$} & 0 & 27.75 & 8.75 & 12 & 59 \\
\hline & & & & & & \\
\hline & & 1 & 26.79 & 6.19 & 12 & 40 \\
\hline \multirow[t]{2}{*}{ ALS } & \multirow[t]{2}{*}{ Loan portfolio/Borrowers (US\$) } & 0 & 1114 & 2594 & 77 & 22252 \\
\hline & & 1 & 1250 & 967 & 102 & 5403 \\
\hline \multirow[t]{2}{*}{ FER } & \multirow[t]{2}{*}{ Financial expenses ratio (\%) } & 0 & 4.52 & 2.91 & 0 & 14 \\
\hline & & 1 & 5.14 & 2.92 & 0 & 16 \\
\hline \multirow[t]{2}{*}{ FRR } & \multirow[t]{2}{*}{ Financial revenues ratio (\%) } & 0 & 23.3 & 11.49 & 8 & 74 \\
\hline & & 1 & 22.23 & 9.31 & 11 & 54 \\
\hline \multirow[t]{2}{*}{ Size } & \multirow[t]{2}{*}{ Natural logarithm of Assets } & 0 & 6.8 & 0.76 & 5 & 8 \\
\hline & & 1 & 7.55 & 0.92 & 6 & 10 \\
\hline
\end{tabular}

Sources: World Bank remittances database, World Economic Outlook, MIX Market, Beck et al. (2008)

Table 2 shows statistics of our sample for binary variables. Regarding the legal status, the sample is dominated by rural banks and cooperatives. When we consider only institutions that have a MTA, cooperatives still dominate the sample, followed by non-banking financial institutions. In terms of regional location, the sample is dominated by EAP MFIs, followed by LAC and African MFIs. LAC MFIs provide the majority of MFIs that have an MTA. 
Table 2: Explanatory binary variables contingency table

\begin{tabular}{|c|c|c|c|c|c|}
\hline Variable & Description & Obs. & $\begin{array}{l}\text { MTA } \\
\text { status }\end{array}$ & Number & $\begin{array}{c}\text { Percentage } \\
\text { of the } \\
\text { sample }\end{array}$ \\
\hline \multirow[t]{2}{*}{ Bank } & \multirow[t]{2}{*}{ Banks } & \multirow[t]{2}{*}{12} & 0 & 6 & $5.2 \%$ \\
\hline & & & 1 & 6 & $5.2 \%$ \\
\hline \multirow[t]{2}{*}{ Coop } & \multirow[t]{2}{*}{ Cooperatives } & \multirow[t]{2}{*}{30} & 0 & 18 & $15.7 \%$ \\
\hline & & & 1 & 12 & $10.5 \%$ \\
\hline \multirow[t]{2}{*}{ NBFI } & \multirow[t]{2}{*}{ Non-bank financial institutions } & \multirow[t]{2}{*}{28} & 0 & 18 & $15.7 \%$ \\
\hline & & & 1 & 10 & $8.7 \%$ \\
\hline \multirow[t]{2}{*}{ Non-profit } & \multirow[t]{2}{*}{ Non-profit } & \multirow[t]{2}{*}{13} & 0 & 12 & $10.5 \%$ \\
\hline & & & 1 & 1 & $0 \%$ \\
\hline \multirow[t]{2}{*}{ Rural banks } & \multirow[t]{2}{*}{ Rural banks } & \multirow[t]{2}{*}{31} & 0 & 26 & $22.8 \%$ \\
\hline & & & 1 & 5 & $4.3 \%$ \\
\hline \multirow[t]{2}{*}{ Africa } & \multirow{2}{*}{ Sub-Saharan Africa } & \multirow[t]{2}{*}{31} & 0 & 25 & $22 \%$ \\
\hline & & & 1 & 6 & $5.2 \%$ \\
\hline \multirow[t]{2}{*}{ SA } & \multirow[t]{2}{*}{ South Asia } & \multirow[t]{2}{*}{12} & 0 & 10 & $8.7 \%$ \\
\hline & & & 1 & 2 & $1.7 \%$ \\
\hline \multirow[t]{2}{*}{ LAC } & \multirow[t]{2}{*}{ Latin America and Caribbean } & \multirow[t]{2}{*}{32} & 0 & 11 & $10 \%$ \\
\hline & & & 1 & 21 & $18.5 \%$ \\
\hline \multirow[t]{2}{*}{ EAP } & \multirow[t]{2}{*}{ East Asia and Pacific } & \multirow[t]{2}{*}{39} & 0 & 34 & $30 \%$ \\
\hline & & & 1 & 5 & $4.4 \%$ \\
\hline
\end{tabular}

\section{ESTIMATES AND RESULTS}

We start the analysis by examining the multicollinearity dimension. Correlations between the continuous explanatory variables are shown in Table 3 . The table stresses that many variables are significantly correlated. However, except for the variations of the GDP, correlation coefficients remain all under 0.8 , the level at which the multicollinearity problem appears (Kennedy, 2008). We have then kept only the one-year variation of the GDP in our regression model. 
Table 3: Correlation coefficient among the explanatory continuous variables

\begin{tabular}{|l|c|c|c|c|c|c|c|}
\hline & $\log$ Deposits & Rem/GDP & GDPpc & $\Delta \mathrm{GDP}(-1)$ & $\Delta \mathrm{GDP}(-2)$ & Inflation & FinInfl. \\
\hline $\log$ Deposits & 1 & & & & & & \\
\hline Rem/GDP & $-0.17^{* * *}$ & 1 & & & & & \\
\hline GDPpc & $0.30^{* * *}$ & -0.03 & 1 & & & & \\
\hline$\Delta \mathrm{GDP}(-1)$ & -0.03 & -0.03 & 0.08 & 1 & & & \\
\hline$\Delta \mathrm{GDP}(-2)$ & -0.07 & $-0.16^{* *}$ & 0.05 & $0.83^{* * *}$ & 1 & & \\
\hline Inflation & -0.09 & $0.24^{* * *}$ & $0.15^{* *}$ & $0.2^{* * *}$ & -0.04 & 1 & \\
\hline FinInflows & $0.25^{* * *}$ & 0.05 & $0.37^{* * *}$ & $0.24^{* * *}$ & 0.01 & 0.07 & 1 \\
\hline Country FinIncl. & $0.27^{* * *}$ & $-0.21^{* * *}$ & $0.52^{* * *}$ & -0.05 & 0.03 & $0.11^{*}$ & -0.05 \\
\hline Size & $0.75^{* * *}$ & -0.07 & $0.13^{* *}$ & -0.04 & -0.09 & -0.09 & $0.11^{*}$ \\
\hline ALS & $0.35^{* * *}$ & $-0.21^{* * *}$ & $-0.22^{* * *}$ & -0.10 & -0.07 & $-0.11^{*}$ & -0.10 \\
\hline FER & $0.15^{* *}$ & $-0.14^{* *}$ & $0.41^{* * *}$ & 0.10 & 0.06 & $0.27^{* * *}$ & $0.2^{* * *}$ \\
\hline FRR & -0.05 & -0.02 & 0.10 & $0.17^{* * *}$ & 0.03 & $0.17^{* * *}$ & $0.44^{* * *}$ \\
\hline
\end{tabular}

Level of significance: ${ }^{* * *}$ if $\mathrm{P}$-value $=<0.01 ;{ }^{* *}$ if $\mathrm{P}$-value $=<0.05 ;{ }^{*}$ if $\mathrm{P}$-value $=<0.10$

Table 3: Correlation coefficient among the explanatory continuous variables (cont.)

\begin{tabular}{|l|c|c|c|c|c|}
\hline & Country FinIncl. & Size & ALS & FER & FRR \\
\hline Country FinIncl. & 1 & & & & \\
\hline Size & 0.06 & 1 & & & \\
\hline ALS & 0.09 & $0.20^{* * *}$ & 1 & & \\
\hline FER & $0.27^{* * *}$ & 0.06 & -0.02 & 1 & \\
\hline FRR & $-0.24^{* * *}$ & 0.005 & -0.23 & $0.23^{* * *}$ & 1 \\
\hline
\end{tabular}

Level of significance: ${ }^{* *}$ if $\mathrm{P}$-value $=<0.01 ; * *$ if $\mathrm{P}$-value $=<0.05 ; *$ if P-value $=<0.10$

Given Houseman test results, we have recourse to random effect estimators. In fact, given the limited temporal dimension of our database, random effect estimators give better results than fixed effect models. Furthermore, we have included time invariant variables (regional dummies, legal status), as we have reason to believe that they have some influence on the dependant variable. Table 4 reports panel-data regression results for the deposit equation. 
Table 4: Regression results

\begin{tabular}{|c|c|c|c|}
\hline \multicolumn{4}{|c|}{ Dependant variable: $\log$ Deposits } \\
\hline & (1) & (2) & (3) \\
\hline MTA & $0.23^{* *}(0.108)$ & $0.23^{* *}(0.110)$ & $0.439 * * *(0.169)$ \\
\hline Africa & $0.24(0.161)$ & $1.046^{* * *}(0.212)$ & $1.144^{* * *}(0.237)$ \\
\hline South Asia & $-0.503^{* * *}(0.183)$ & & \\
\hline East Asia and P. & $-0.012(0.131)$ & $0.486^{* * *}(0.170)$ & $0.543^{* * *}(0.177)$ \\
\hline Latin America and C. & & $0.693^{* * *}(0.210)$ & $0.768^{* * *}(0.218)$ \\
\hline Coop & & $-0.364(0.451)$ & $-0.425(0.456)$ \\
\hline NBFI & & $-0.139(0.436)$ & $-0.156(0.448)$ \\
\hline Bank & & $0.064(0.410)$ & $-0.004(0.423)$ \\
\hline Others & & $0.002(0.442)$ & $-0.046(0.449)$ \\
\hline ALS & $0.33^{* * *}(0.90)$ & $0.261^{* * *}(0.098)$ & $0.275^{* * *}(0.1)$ \\
\hline FRR & $-0.012^{* * *}(0.004)$ & $-0.015^{* * *}(0.005)$ & $-0.017^{* * *}(0.005)$ \\
\hline FER & & $0.013(0.017)$ & $0.012(0.018)$ \\
\hline Size & $0.892^{* * *}(0.056)$ & $0.864^{* * *}(0.063)$ & $0.844^{* * *}(0.065)$ \\
\hline Rem/GDP & & & $0.010(0.012)$ \\
\hline MTA*Rem/GDP & & & $-0.029(0.018)$ \\
\hline K Inflows & $0.013^{* * *}(0.004)$ & $0.012^{* * *}(0.004)$ & $0.011^{* *}(0.004)$ \\
\hline FinInclusion & $0.019^{* * *}(0.007)$ & $0.018^{* *}(0.007)$ & $0.017^{* *}(0.007)$ \\
\hline GDPpc & $0.363^{* *}(0.156)$ & $0.358^{* *}(0.171)$ & $0.373^{* *}(0.178)$ \\
\hline$\Delta \mathrm{CPI}$ & & & $0.009(0.015)$ \\
\hline Constant & $-1.346^{* *}(0.651)$ & $-1.568^{* *}(0.730)$ & $-1.571^{* *}(0.783)$ \\
\hline $\mathrm{Nb}$ of obs & 228 & 228 & 228 \\
\hline $\mathrm{R}^{2}$ & 0.74 & 0.75 & 0.76 \\
\hline
\end{tabular}

Level of significance: ${ }^{* * *}$ if $\mathrm{P}$-value $=<0.01 ;{ }^{* *}$ if $\mathrm{P}$-value $=<0.05 ; *$ if $\mathrm{P}$-value $=<0.10$

In order to assess the validity of our model, we test different empirical specifications of the equation. In Equation (1), we have a benchmark specification with includes only the significant parameters. In equations (2) and (3) we include additional MFI parameters, (legal status and FER), respectively, and macroeconomic variables, (GDP related variables, remittances and inflation), with an interaction term, remittance flows and MTA, to see if MTA is able to mediate the effect of remittances.

As expected, MTA always positively contributes to the volume of de- 
posits in MFIs. The coefficient related to our variable of interest is positive and significant in all the specifications (at $1 \%$ and $5 \%$ ). This means that MFIs providing money transfer services have a significantly higher level of deposits than the ones that do not. Additional deposits may come from remittance flows that have transited through MFIs thanks to these services. This result confirms the hypothesis that MFIs can contribute in turning remittances into deposits, which increases the impact of remittances on long term growth through the funding of productive investments.

The region matters when we consider the level of deposits mobilized by MFIs. Regarding regional dummies, it appears that south Asian MFIs have a significantly lower level of deposits compared to MFIs from any other region.

The ALS coefficient is always positive and strongly significant, meaning the richer the client, the greater their ability to save money. The FRR coefficient is always significant at $1 \%$ and negative, as expected. The higher the interest paid on credits, the fewer the clients who will have money available for deposits.

Regarding confidence towards the institution, it appears that bigger MFIs attract more deposits than smaller institutions, as they are certainly perceived to be better managed that the latter. Legal status dummies are never significant in our regressions.

Turning to macroeconomic variables, the coefficient of financial inclusion is always positive and significant. As it is measured as a percentage of the adult population with access to a financial intermediary in the country, the amount of deposits collected by MFIs, as financial intermediaries, increases with this percentage. Regarding the level of financial openness, the coefficient is always positive and strongly significant. This means that private capital inflows to a country increase its inhabitants' capacity to save, which increase their deposits in financial institutions. Finally, the coefficient of GDP per capita, which captures the standard of living of the country, is also positive and significant, as expected.

The coefficients of the remaining variables are not significant. It is worth mentioning that the non significance of the FER coefficient is in line with the literature which states that the interest rate paid on deposits by financial institutions is not, for the majority of poor people, the main determinant of their decision to put their money on an account in a financial institution. Remittance flows coefficient also is not significant. This means that we do not find a direct impact of remittance flows within the country on the volume of deposits collected by MFIs. Their impact on MFIs' deposits may come from the interaction between remittance flows and the provision of money trans- 
fer services by MFIs. However, the interaction term coefficient is not significant in our regression.

In summary, our empirical results confirm our hypothesis: operating on the money transfer market contributes to increasing the volume of deposits mobilized by MFIs, because these institutions contribute to the financial inclusion of remittance receivers who mainly lack bank access. Results also confirm some previous results related to remittances and to deposits in microfinance, such as the importance of trust in the MFIs and the fact that remuneration of deposits does not matter for the majority of depositors.

\section{CONCLUSION}

By measuring the effect of money transfer activities on deposits in MFIs, this paper analyses the potential role of microfinance as a channel to improve the growth impact of remittances in developing countries. Actually, given the majority of remittance senders and receivers are excluded from traditional banks in developing countries, MFIs may be the only formal financial intermediaries able to recycle remittance flows into the economy, improving their growth impact.

The results suggest a positive and significant effect of MTA on the level of deposits mobilized by the MFIs in our sample, which goes in the scheme of a role for microfinance when thinking about improving the growth impact of remittances. However, this result should be considered carefully, given the limited size of the database both in terms of year and number of observations. Furthermore, causality issues are raised regarding the supply of a MTA and the demand for deposit facilities.

Thus, we can analyze the question from two different perspectives, leading to different conclusions. Firstly, we can argue that MFIs enter the remittance market by providing money transfer services because there is a need for this, and for further financial services, from their, potential, clients who are remittance receivers and migrants. According to this 'demand' point of view, MFIs can contribute to recycle remittance flows into the financial system by contributing to the financial inclusion of remittance receivers and $\mathrm{mi}-$ grants thanks to the supply of adapted financial products. The occurrence of this assumption can therefore be measured by considering the involvement of MFIs on the remittance market as a determinant of financial inclusion indicators. This is the perspective adopted in this paper. (MTA as a determinant of deposits) Secondly, we can argue that MFIs are interested in operating on the remittance market because working with migrants potentially 
contributes to the improvement of their financial and social performance. According to the forecast by MFIs, remittance market opportunities as well as MFI characteristics will determine the offer of money transfer services by MFIs. This supply approach therefore leads to the consideration of money transfers activities in MFIs as depending on remittance market opportunities such as remittances becoming deposits.

Causality problems therefore exist. However, given currently existing data on MFI involvement on the remittance market we cannot simultaneously consider both perspectives in order to implement causality treatment techniques. In fact, there is no history or indication of MFI involvement we use in our regressions, thus we are not able to construct instrumental variables such as lagged values for our variable of interest to eliminate econometric issues in our regressions. Nevertheless, by studying one of these two approaches, we already contribute to some extent to the knowledge by putting in perspective different issues at stake for the microfinance industry, and the main implication of our result is the promotion of the supply of money transfer by MFIs in developing countries.

From the microfinance industry perspective, more than the technical aspects to be considered by MFIs that are willing to enter the remittances market, other issues need to be carefully assessed. One of the main potential consequences of MTA of MFIs is the additional available financial resources through migrants and deposits from remittance receivers. However, these deposits may have specific characteristics, especially in terms of volatility, as depositors' behavior may differ from the 'traditional' depositors' behavior, higher average amount deposited and longer term deposits for instance, which may lead to a higher sensitivity to interest rates on deposits. Using migrants' money as a source of funding may then imply that MFIs acquire additional management capacity, to be able to overcome this induced higher liquidity risk. Managers should be able to determine whether migrants' money only increases their liquidities or short term funds, or are in fact, longer term resources.

Another issue to be considered is that the MTA may penalize microfinance clients who are not remittance receivers. Literature suggests that remittances can be used as collateral for loans. Descriptive statistics highlight the fact that remittance receivers are economically better-off as compared to non-remittance receivers, with the highest ALS, even if the difference is not statistically significant. There may be a danger that, with too much emphasis on remittance as a source of funding for MFIs, clients that do not receive remittances may be weeded out of MFIs' portfolios. The same issue may hold for depositors (negative effect on local depositors). 
Finally, the impact of microfinance on remitting costs needs to be evidenced, as it can be ambiguous. Microfinance institutions are expected to contribute to increased competition on the money transfer market, which should lead to lower sending charges for remitters. Furthermore, MFIs social objectives may also prevent them from charging high commissions compared to other money transfer operators. All else equal, lower sending charges will increase the amount of money available for deposits.

However, offering competitively low commission rates on money transfers may be harder for MFIs than for the other formal and informal institutions that currently operate in the money transfer market, because MFIs face higher transaction costs in their activities, lending, savings collection, than other financial operators, due to less availability of client information and activities in remote areas, as an example. Furthermore, remitters' transactions and financial costs will depend on the business model implemented by MFIs in order to enter the remittances market, and on their negotiation power. In the case of operating as sub-agents of money transfer operators (MTOs) ${ }^{17}$, transaction costs for the remitter will depend on the MTO network in the country of migration. Regarding financial costs, MFIs are not really in a position to do anything about the level of commission charges paid by remitters. Not only do MTOs offer their services at a higher cost compared to the other players on the market, rather, in this business model there are also a large number of intermediaries. The more intermediaries there are between the remitter and the recipient of the remittance, the higher the commission charges.

In the cases when MFIs are owners of a remittances product, remitting costs will be - at least in principle - lower, since there are less intermediaries involved in the transaction and also due to the fact that, given the social concerns of the MFIs, they are less likely to apply commission charges designed to generate an excess level of profit. The impact of MFIs on remitting costs has not been empirically studied yet.

In general, the sustainability of the MTA for MFIs should be assessed. Thus, as argued earlier, the MTA can bring additional revenues to the MFI mainly in terms of commissions, additional deposits and, to some extent, economies on screening costs. However, it also can imply additional operational costs related to the management of the risks involved by the activity, such as liquidity risk. This gives avenue for further research, as there is little literature to our knowledge that covers this aspect.

17 The formal money transfers market is dominated by MTOs, with Western Union being the main one. Sending money through large MTOs is the most expensive channel for remitters compared to other formal actors. See Sukadi Mata (2006). 


\section{Appendix 1: The sample, by country 18}

Latin America and Caribbean

Bolivia: Banco Los Andes ProCredit, BancoSol, Eco Futuro, FIE, PRODEM

Colombia: Finamerica

Ecuador: ProCredit - ECU, Banco Solidario, COAC Mushuc Runa, COAC Acción Rural, COAC San José, COAC Jardín Azuayo, COAC Maquita Cushunchic, COAC Sac Aiet, FINCA - ECU

El Salvador: ACCOVI

Haiti: $\quad$ Fonkoze

Honduras: FINSOL, ODEF OPDF

Mexico:

Caja Popular Mexicana, FINCOMUN

Peru:

CMAC Arequipa, CMAC Huancayo, CMAC Maynas, CMAC Sullana, CMAC Tacna, CMAC Trujillo, CMAC Del Santa, CRAC Caja Nor, COOPAC Santo Cristo, COOPAC San Martin, MiBanco

East Asia and Pacific

Cambodia: $\quad$ ACLEDA, AMRET, AMK, HKL, CREDIT, Maxima

Indonesia: BPR AK, LPD Kuta, LPD Pecatu, LPD Panjer, LPD Ketewel, LPD Bedha, LPD Kukuh, BPR Eka Ayu, BPR PKT, LPD Celuk, LPD Buahan

Philippines: NWTF, Life Bank, CARD Bank, $1^{\text {st }}$ Valley Bank, Cantilan Bank, CBMO, BCB

Philippines: Banco Santiago de Libon, Bangko Kabayan, RB Digos, CMEDFI, Valiant RB, RB Solano, New RB of Victorias, Bangko Mabuhay, RB Sto. Tomas, Partner RB Cotabato

Samoa: $\quad$ SPBD

Vietnam: $\quad$ CEP, TYM, Binhminh CDC

South Asia

Nepal: $\quad$ Nirdhan, SB Bank, MGBB, PGBB, CBB, DD Bank, CSD NGO, JSCCS

18 www.mixmarket.org. 
Pakistan: $\quad$ Kashf, FMFB - Pakistan

Sri Lanka: Sabaragamuwa, SEEDS

Africa

Benin: $\quad$ FECECAM, CBDIDA/RENACA, MDB, CODES

Mali: Kafo, Nyesigiso, Miselini, Kondo Jigima, CVECA Kita/ Bafoulabé, PASECA-Kayes, Réseau KARABARA, CACOEC SUDUDIAWDI

Mozambique: NovoBanco - MOZ, SOCREMO

Niger:

MECREF

Rwanda: CFE

Senegal: $\quad$ CMS, PAMECAS, ACEP, U-IMCEC, DJOMEC, MECBAS

Togo: FUCEC Togo, WAGES, MICROFUND

Uganda: Centenary Bank, FINCA-UGA, UML, U-Trust/UWFT, CML, KYAPS

\section{Appendix 2:}

Sample of the 34 MFIs with a money transfer activity, by legal status

Bank:

Cooperative:

Rural bank:

Non-profit institution:
Banco Los Andes ProCredit, Bancosol, Banco Solidario, MiBanco, BRI, NovoBanco - MOZ COAC Mushuc Runa, COAC Accion Rural, COAC San José, COAC Jardin Azuayo, Caja Popular Mexicana, COOPAC Santo Cristo, COOPAC San Martin, FECECAM, Nyesigiso, CVECA Kita/Bafoulabé, ACEP, UIMCEC

Non-bank financial institution: FIE, PRODEM, ACCOVI, FINSOl, FINCOMUN, CMAC Huancayo, CMAC Maynas, CMAC Sullana, CRAC Caja Nor, FMFB Pakistan

$1^{\text {st }}$ Valley Bank, New RB of Victorias, RB Sto. Tomas, Partner RB Cotabato, CBB

Fonkoze 


\section{References}

Acción, 2004, "Leveraging Impact of Remittances Through Microfinance Products: Perspectives from Market Research", Insight, Vol. 10, pp. 1-16.

Aggarwal R., A. Demirguc-Kunt and M. Martinez Peria, 2006, “Do Worker Remittances Promote Financial Development?", World Bank Policy Research Working Papers, No. 3957.

Aghion P., E. Caroli and C. Garcia-Penalosa, 1999, “Inequality and Economic Growth: The Perspective of the New Growth Theories", Journal of Economic Literature, Vol. 37, No. 4, pp. 1615-1660.

Alfieri A., I. Havinga and V. Hvidsten, 2005, "Definition of Remittances and Relevant BMP5 Flows", United Nations Statistics Division, Meeting of the Technical Subgroup of the Task Force on International Trade in Services, Movement of Natural Persons. Mode 4, Issue paper 1.

Amuedo-Dorantes C. and C. Bansak, 2006, "Money Transfers among Banked and Unbanked Mexican Immigrants", Southern Economic Journal, Vol. 73, No. 2, pp. 374401.

Amuedo-Dorantes C. and S. Pozo, 2006, "Remittances as Insurance: Evidence from Mexican Migrants", Journal of Population Economics, Vol. 19, No. 2, pp. 227-254.

Armendariz B. and J. Morduch, 2009, The Economics of Microfinance, MIT Press, Cambridge, MA.

Azam J-P. and F. Gubert, 2005, "Those in Kayes. The Impact of Remittances on Their Recipients in Africa", Revue Economique, Vol. 56, No. 6, pp. 1331-1358.

Beck T., A. Demirgüç-Kunt and M. Soledad Martinez Peria, 2008, "Banking Services for Everyone? Barriers to Bank Access and Use around the World", World Bank Economic Review, Vol. 22, pp. 397-430.

Deshpande R. and J. Glisovic-Mezieres, 2007, "The True Cost of Deposit Mobilization", Draft report, CGAP.

Faini R., 2007, "Migrations et Transferts de Fonds. Impact sur Les Pays D'Origine", Revue d'Economie du Développement, Vol. 21, No. 2, pp. 153-182.

Gheeraerts L., R. Sukadi Mata and D. Traça, 2010, “Remittances and Domestic Investment in Developing Countries: An Analysis of the Role of Financial Sector Development", Working Papers CEB 10-013.RS, Université Libre de Bruxelles, Solvay Brussels School of Economics and Management, Centre Emile Bernheim (CEB).

Giuliano P. and M. Ruiz-Arranz, 2009, "Remittances, Financial Development, and Growth", Journal of Development Economics, Vol. 90, No. 1, pp. 144-152.

Gonzalez-Vega C., 1998, "Microfinance: Broader Achievements and New Challenges", Economics and Sociology Occasional Paper No. 2062, The Ohio State University.

Gupta S., C. Patillo, and S. Wagh, 2009, "Impact of Remittances on Poverty and Financial Development in Sub-Saharan Africa", World Development, Vol. 37, No. 1, pp. 104-115. 
Hirschland M. (Ed.), 2005, Savings Services for the Poor: An Operational Guide. Kumarian Press, Bloomfield.

Huang W., 2006, "Emerging Markets Financial Openness and Financial Development", University of Bristol Discussion Paper, No. 06/588.

Isern J., W. Donges and J. Smith, 2006, Making Money Transfers Work for Microfinance Institutions. A Technical Guide to Developing and Delivering Money Transfers. GCAP/World Bank, Washington.

Kennedy P., 2008, A guide to Econometrics (6 $6^{\text {th }}$ ed.), Blackwell Publishing, Oxford.

Krauss N. and I. Walter, 2008, “Can Microfinance Reduce Portfolio Volatility?", SSRN Working Paper Series.

Microrate and IADB, 2003, Performance Indicators for Microfinance Institutions. Technical guide (3 $3^{\text {rd }}$ edition), Microrate and IADB, Washington.

Mundaca B.G., 2009, “Remittances, Financial Markets Development and Economic Growth: The Case of Latin America and Caribbean", Review of Development Economics, Vol. 13, No. 2, pp. 288-303.

Orozco M., 2008, "Remittances and Microfinance in Latin America and the Caribbean. Steps Forward on a Long Road Ahead", USAID microREPORT No. 118.

Orozco M., 2007, "Sending Money Home: Worldwide Remittance Flows to Developing and Transition Countries", IFAD.

Orozco M. and E. Hamilton, 2006, "Remittances and MFI Intermediation: Issues and Lessons", in Shaw, J. (Ed), 2006, Remittances, Microfinance and Development: Building The Links. Volume 1: a global view, FDC, Brisbane.

Orozco M. and R. Fedewa, 2005, Leveraging Efforts on Remittances and Financial Intermediation, Report commissioned by the Inter-American Development Bank, InterAmerican Dialogue.

Ponsot F., 2006, L'offre de services de transfert d'argent par des institutions de microfinance: le cas du Sénégal, CAPAF.

Sukadi Mata R., 2010, “Transferts d'Argent des Migrants: Enjeux pour la Microfinance", Techniques Financières et Développement, Vol. 101 - Spécial Microfinance, pp. 91-99.

Sukadi Mata R., 2006, “Les IMF sur le Marché des Transferts d'Argent: Quel Positionnement Adopter?", European Dialogue, Vol. 36, pp. 77-98.

Toxopeus H.S. and R. Lensink, 2007, "Remittances and Financial Inclusion in Development", UNU - WIDER Research Paper 2007/49.

World Bank, 2011, Remittances Database available on www.worldbank.org.

Wright G.A.N., 2003, Designing Savings Services for the Poor, Prepared for the Micro Banking Bulletin, MicroSave. 


\section{Résumé}

A partir d'une base de données regroupant 114 IMF d'Afrique, d'Asie du sud, d'Amérique latine et Caraibes, de l'Asie de l'est et du pacifique, cet article se propose de tester l'hypothèse selon laquelle les institutions de microfinance (IMF) sont capables de transformer les transferts d'argent des migrants en dépôts. Plus précisément, il s'intéresse à l'effet de l'activité de transfert d'argent sur les dépôts dans les IMF. Les résultats montrent un effet positif et significatif de ladite activité sur les dépôts. 
